\title{
SPECIES AND STAND DYNAMICS IN THE MIXED WOODS OF QUEBEC'S SOUTHERN BOREAL FOREST
}

\author{
YVES BERGERON ${ }^{1}$ \\ Groupe de Recherche en Écologie Forestière Inter-universitaire, Université du Québec, CP 8888, \\ Succursale Centre-ville, Montréal, Québec, Canada H3C 3P8
}

\begin{abstract}
In order to test whether changes in forest composition observed while sampling portions of the landscape originating from different fires may be explained by standlevel processes, I reconstructed species and stand dynamics for mesic sites in the mixedboreal forests of Quebec. The stands studied are located in the forest surrounding Lake Duparquet in northwestern Quebec and originated from eight successive fires representing a chronosequence of $230 \mathrm{yr}$. Tree composition and ecological characteristics were assessed in 313 quadrats distributed systematically within the burned areas; one representative stand per fire, presenting the average species composition for clay soils with a moderate moisture regime, was selected for detailed dendroecological analysis. All living and dead stems (> $1 \mathrm{~cm} \mathrm{dbh}$ ) were mapped and cut down in a $20 \times 20 \mathrm{~m}$ quadrat. Cross sections collected at the root collar and at every meter were analyzed using standard dendrochronological techniques. The age of the stand before the last fire was estimated using snags and logs located in, or in the vicinity of, each quadrat.
\end{abstract}

A PCA (principal-components analysis) ordination of all quadrats shows a gradual change with time since fire from stands dominated by hardwoods (aspen and paper birch), to mixed stands with an important white spruce component, to coniferous stands dominated by balsam fir and white cedar. Despite variations in the age and composition of the stands before the last fire, they generally follow a common pattern characterized by post-fire hardwood dominance. Age structures show successive waves of aspen, birch, and fir recruitment, corresponding respectively to the post-fire cohort, the gradual dismissal of the first aspen cohort, and spruce budworm outbreaks. Each of these waves corresponds to a decrease in hardwoods and an increase in the conifer component of the stand. Suppressed white spruce individuals, recruited primarily as part of the post-fire cohort, experienced growth releases following the dismissal of the first aspen cohorts. White cedar increased in abundance late in succession and tended to outcompete balsam fir in old coniferous stands severely affected by spruce budworm outbreaks.

The observed multi-cohort process contrasts with the simple replacement of hardwoods by conifers as suggested by observations of differential growth rates. The patchy distribution of conifer regeneration together with the poorer ability of conifers to rapidly fill gaps may explain why hardwoods are successfully recruited. This gradual rate of change, occurring over several generations, results in the maintenance of an important hardwood component in most stands even in the absence of fire. After $230 \mathrm{yr}$, stands are still mainly composed of trees originating from punctuated events such as fire, the gradual dismissal of the first aspen cohort, or spruce budworm outbreaks. This contrasts with old-growth boreal forests dominated by spruces in which a quasi-equilibrium is maintained by small canopy disturbances. The study confirms that changes in forest composition observed while sampling portions of the landscape originating from different fires may be explained by simple processes occurring at the stand level.

Key words: aspen; balsam fir; boreal forest disturbance regimes; canopy gaps; dendroecology; forest fire; forest succession; mixed woods; old-growth forest; post-disturbance species dynamics; spruce budworm; stand dynamics, southern Quebec boreal forest.

\section{INTRODUCTION}

In Canada's boreal forests, fire regimes are generally characterized by high-intensity crown fires that initiate secondary-succession processes in the burnt areas (Heinselman 1981, Van Wagner 1983). In most parts of the boreal forest, the fire cycle is shorter than the life-span

Manuscript received 14 December 1998; revised 4 June 1999; accepted 4 June 1999; final version received 7 July 1999.

${ }^{1}$ E-mail: bergeron.yves@uqam.ca of the dominant species, thereby favoring a post-fire composition similar to the pre-fire composition (Johnson 1992). This phenomenon is typical of stands dominated by trees bearing serotinous cones such as black spruce (Picea mariana (Mill.) BSP.) and jack pine (Pinus banksiana Ait.), as well as by species with root systems that survive fire such as paper birch (Betula papyrifera Marsh.) and aspen (Populus tremuloides Michx.) (Viereck 1983, Gagnon 1989, Gauthier et al. 1993). While in most parts of the boreal forest short fire cycles limit 
changes in canopy composition, in the southern part of the boreal forest longer fire cycles permit changes in species dominance to occur (Dix and Swan 1971, Carleton and Maycock 1978, Cogbill 1985, Bergeron and Dubuc 1989, Frelich and Reich 1995). It is generally accepted that this change in canopy composition is a result of differential growth rates among species (Viereck 1983) and not to a true replacement of species as driven by inhibition or facilitation processes (Connell and Slatyer 1977). In fact many studies report that late successional species can invade burnt areas immediately following fire (Johnson 1992, Bergeron and Charron 1994). However, Bergeron and Dubuc (1989) suggest that the recruitment of balsam fir (Abies balsamea (L.) Mill.) and eastern white cedar (Thuja occidentalis L.) might be delayed until suitable seedbeds (dead wood and moss) become more abundant.

Although there is a general relationship between the time since fire and forest composition over large landscapes (Bergeron and Dubuc 1989, Frelich and Reich 1995), the occurrence of and the processes involved in the change from one composition to another at the stand level is still strongly debated (Johnson 1992). This is partly due to the fact that most studies of the boreal forest have emphasized post-fire succession, while disturbance dynamics affecting old post-fire stands are rarely studied. At this stage, canopy disturbance replaces fire as the process controlling stand dynamics (Oliver and Larson 1990). In the southeastern boreal forest, large canopy openings caused by spruce budworm outbreaks (Blais 1983, Morin et al. 1993) may lead to a cyclical replacement of mature stands of balsam fir (MacLean 1980, Morin 1994). Many studies have also shown the importance of small canopy disturbances in the dynamics of old-growth boreal forests (Qinghong and Hytteborn 1991, Hofgaard 1993, Kuuluvainen 1994).

In the absence of permanent plots established for long-enough periods of time to observe succession directly, stand dynamics have generally been inferred from current stand characteristics. Differences in stand composition on similar sites have often been interpreted as succession (Carleton and Maycock 1978, Bergeron and Bouchard 1984, Cogbill 1985). Species diameter or height distributions have been used as indicators of past and future forest succession (Carleton and Maycock 1978, Bergeron and Dubuc 1989). These approaches have suffered from criticisms because differences in stand composition may be related more to fire behavior than to time elapsed since fire (Johnson 1992) and because size structure may reflect differential growth rates more than species replacement (Viereck 1983). Dendroecology is an alternative tool permitting the reconstruction of stand history and species dynamics. It has been successfully applied in many different forest types for this purpose (e.g., Lorimer 1985, Johnson and Fryer 1989). However, with the exception of a few studies on wind and insect disturbances (Morin 1990, Payette et al. 1990), there are very few dendroecological studies addressing post-fire species dynamics in the southern boreal forest. Moreover, very few studies have, like the present one, addressed the problem using both a chronosequence approach at the landscape level and detailed stand reconstruction at the local stand level.

In a previous study (Bergeron and Charron 1994), we assessed the use of such a dendroecological approach to the study of post-fire succession in the southern boreal forest. In the present study, this approach is applied to the reconstruction of a long post-fire succession in Québec's southern boreal forest. Eight areas, originating from fires that occurred at different times, were used to reconstruct species and stand dynamics over a 230-yr period. My objective was to document changes in forest composition at the landscape level and to analyze the processes responsible for tree-species replacement at the stand level. It was further hypothesized that changes in forest composition observed while sampling portions of the landscape originating from different fires may be explained by stand-level processes. Despite the multiple pathways of forest succession that are present after fire, I also hypothesized that a convergence towards dominance by shade-tolerant conifers occurs. This pattern of convergence is mainly driven, at the stand level, by species life history such as recruitment, longevity, and growth. In other words species replacement occurs with time since fire and is better explained by species tolerance than by inhibition or facilitation processes (Connell and Slatyer 1977).

\section{STUdy Site}

The study sites (Fig. 1) are in the forests surrounding Lake Duparquet, located south of Lake Abitibi in northwestern Québec $\left(79^{\circ} 1^{\prime} \mathrm{W}, 48^{\circ} 30^{\prime} \mathrm{N}\right)$. Lake Duparquet is part of a vast watershed that drains northward through Lake Abitibi to James Bay.

The surrounding region is part of the northern Clay Belt of Québec and Ontario, a large physiographic region created by lacustrine deposits left after the maximum post-Wisconsinian extension of the proglacial lakes Barlow and Ojibway (Veillette 1994). The closest meteorological station to our study area is at La Sarre, $\sim 42 \mathrm{~km}$ to the north. The climate is cold temperate with a mean (1961-1990) annual temperature of $0.8^{\circ} \mathrm{C}$ and a mean annual precipitation of $856.8 \mathrm{~mm}$ (Environment Canada 1993). Snow represents $25 \%$ of the yearly total precipitation. Most liquid precipitation falls during the growing season but evaporation can limit plant growth in both June and July. The mean frost-free period is 64 $\mathrm{d}$ but freezing can occur at any time.

Lake Duparquet is located in the southeastern boreal forest within Rowe's (1972) Missinaibi-Cabonga forest section. Balsam fir is the dominant species while black spruce, white spruce (Picea glauca (Moench) Voss), and paper birch are also important components of the forest. Stands of pioneer species, such as jack pine, 
$79^{\circ} 15^{\prime}$

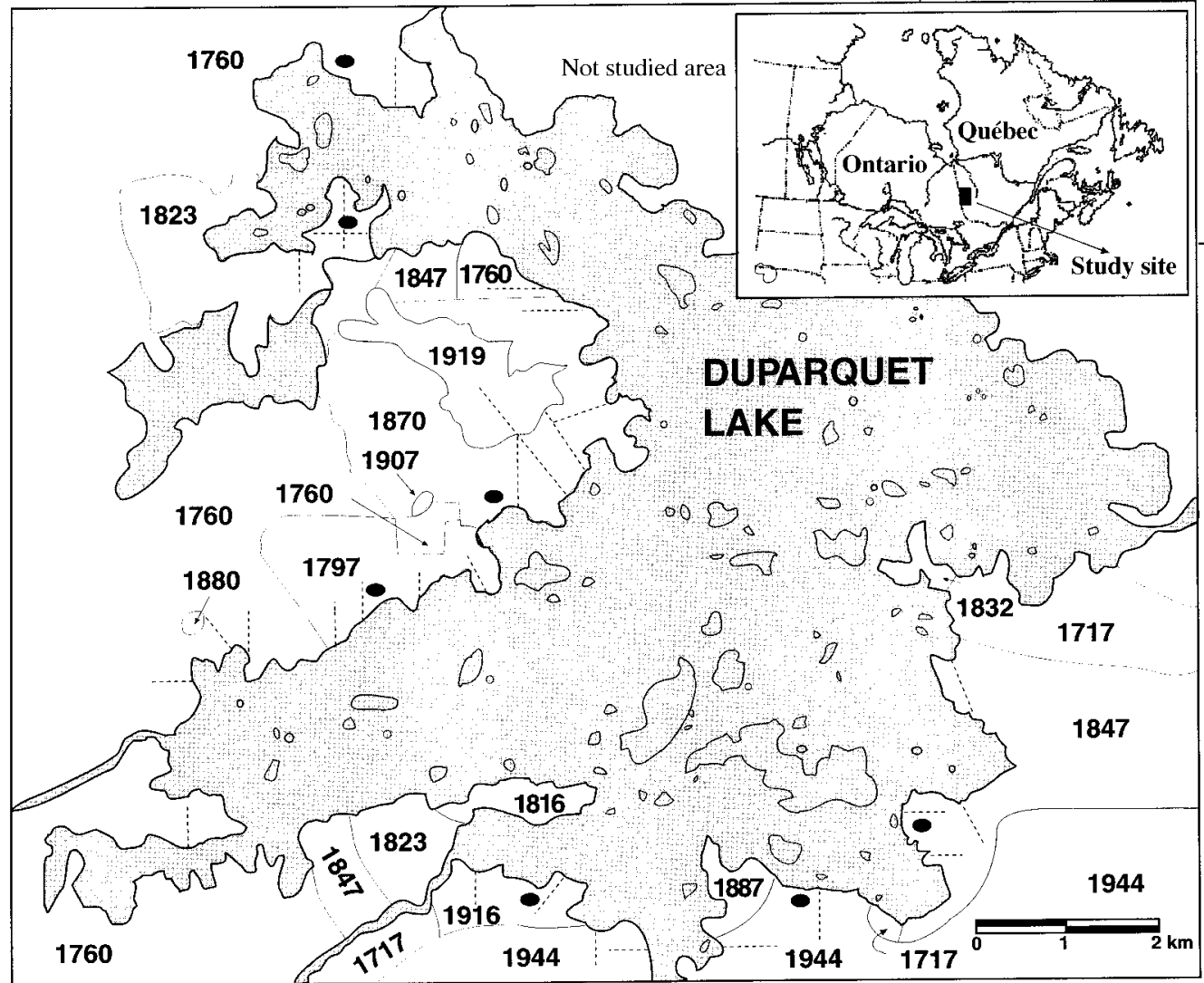

FIG. 1. Map of Lake Duparquet (Canada) showing the location of the transects (dashed lines) and the different fire areas (with year of fire). Black ovals indicate the location of the quadrats used for detailed dendroecological analysis. Note that the site of the 1964 fire is located about $10 \mathrm{~km}$ northwest of the lake.

aspen, and paper birch, occupy large areas following disturbance (Bergeron and Bouchard 1984).

The periodic occurrence of fires since the end of the last glaciation ( $~ 8000 \mathrm{BP})$ has been documented from lake sediments (Liu 1990, Richard 1993). The fire regime during the last $300 \mathrm{yr}$ has been reconstructed by Bergeron (1991) and Dansereau and Bergeron (1993). The mainland fire regime is characterized by high-in-

TABLE 1. Characteristics of the eight studied fire areas in forests surrounding Lake Duparquet (northwestern Quebec, Canada).

\begin{tabular}{cccc}
\hline \hline Fire date & Fire area (ha) & Stand age $(\mathrm{yr}) \dagger$ & Interval $(\mathrm{yr})$ \\
\hline 1964 & 362 & 26 & 26 \\
1944 & $>298 \ddagger$ & 46 & 30 \\
1916 & 35 & 74 & 28 \\
1870 & 555 & 120 & 46 \\
1847 & 122 & 143 & 23 \\
1823 & 288 & 167 & 24 \\
1797 & 178 & 193 & 26 \\
1760 & $>7760 \ddagger$ & 230 & 37 \\
\hline
\end{tabular}

$\uparrow$ At the sampling date (1990).

$\$$ The extent of fire is a minimum estimate because the fire burned a larger area than the area under investigation. tensity fires covering large areas, especially in flat topography. The fire cycle has been estimated as $63 \mathrm{yr}$ for the period before 1870 and $>99 \mathrm{yr}$ after 1870 . Three major spruce budworm (Choristoneura fumiferana) outbreaks during 1919-1929, 1930-1950, and 19701987 have been reported for this century (Morin et al. 1993). The forest tent caterpillar (Malacosoma disstria) is the major pest in hardwood stands, and severe outbreaks were reported in the area during the 20th century (Bergeron and Charron 1994). Forest harvesting started in the region as soon as the transcontinental railway was opened in 1910. However, it was not until 1978 that large-scale clearcuts disturbed the western part of the Lake Duparquet area (Harvey and Bergeron 1989).

The sampled stands originated following eight different fires: 1964, 1944, 1916, 1870, 1847, 1823, 1797, and 1760 (Table 1, Fig. 1). Fire date and area have been delimited in previous studies (Bergeron 1991, Dansereau and Bergeron 1993) using fire scars and cohorts of fire-prone species. Maps and reports on the 1964 and 1944 fires were found in the archives of the Société de protection contre les feux du Québec (Québec, Canada). To control for the effects of site characteristics, all 
studied sites were located on clay deposits with a moderate moisture regime (Brais and Camiré 1992). All sites are characterized by gentle slope and soils are classified as gray luvisols (Bergeron et al. 1983).

\section{Methods}

\section{Forest composition}

Tree composition and ecological characteristics were sampled in quadrats distributed every $50 \mathrm{~m}$ along transects established within each of the burnt areas. The number of sampled quadrats varied among fires according to the area covered by clay deposits: $1964(n=5$ quadrats $), 1944(n=51), 1916(n=43), 1870(n=$ 45), $1847(n=62), 1823(n=42), 1797(n=17)$, and $1760(n=48)$. Trees $(>5 \mathrm{~cm}$ in diameter at breast height [dbh]) were tallied in a $16 \times 16 \mathrm{~m}$ quadrat, saplings (1$5 \mathrm{~cm} \mathrm{dbh})$ in an $8 \times 8 \mathrm{~m}$ quadrat and seedlings $(<1 \mathrm{~cm}$ $\mathrm{dbh}$ ) in twelve $1 \times 1 \mathrm{~m}$ quadrats. Stand origin (fire year) was determined from the fire map (Fig. 1) and verified, when necessary, by coring trees. Soil texture (hand determined, Jones et al. 1983), slope (in percentage), stoniness (in percentage), and moisture regime (Brais and Camiré 1992) were recorded at each site.

An ordination using a principal-components analysis (PCA) was performed using species' relative basal area (ter Braak 1988). In order to normalize the distribution of species abundance, values were first log transformed using a Napierran logarithm. The stands used for dendroecological analysis (see below) were passively positioned a posteriori in the ordination diagram to assess their composition with respect to the entire burnt area.

Finally in order to describe general trends in the abundance of each tree species in relation to time since fire, polynomial regressions based on raw basal areas were performed.

\section{Dendroecological analysis}

One site per fire was subjectively selected for a detailed dendroecological analysis. Each site had to be representative of the average composition for a specific fire year and free of any sign of anthropogenic disturbance. In a $20 \times 20 \mathrm{~m}$ quadrat, all living and dead tree stems $\geq 1 \mathrm{~cm}$ dbh were tagged and mapped using a two-coordinate system. Trees were cut down and cross sections $\geq 2 \mathrm{~cm}$ in diameter including bark were collected at the root collar and at every subsequent meter in order to create cumulative height date curves (Johnson and Fryer 1989). We cut a number of trees below the humus surface to asses the possible underestimation of tree age compared with samples collected at the humus level. The depth of the humus layer in mesic stands is rarely over $10 \mathrm{~cm}$. Ages below humus layers were not significantly different and thus we did not correct our age estimates. Cross sections were collected from dead standing trees and from logs when possible. All tree saplings $<1 \mathrm{~cm} \mathrm{dbh}$ and $>10 \mathrm{~cm}$ in height were collected and aged at the collar. Tree seedlings $\leq 10 \mathrm{~cm}$ in height were collected and aged in ten $1 \times$ $1 \mathrm{~m}$ quadrats randomly distributed within the $20 \times 20$ $\mathrm{m}$ quadrat. In addition, in cases where some species were not represented in sufficient numbers, we searched for other individuals in 1-ha area around the $20 \times 20$ m quadrats. Only cores were collected from these additional trees and they were used solely to complement our age-structure data.

The identification and dating of snags and logs found in the burnt forest were used to estimate the origin and composition of the pre-fire stand. Snags and logs were collected in, or in the vicinity of, the $20 \times 20$ m quadrats. Whenever possible, the estimated date was confirmed by the year of the last recorded fire in an adjacent area (Fig. 1). The crossdating of white cedar and jack pine snags was accomplished using previously developed chronologies from the same area (Archambault and Bergeron 1992, Dansereau and Bergeron 1993).

Tree-ring widths were measured, using a Henson (Mission Viejo, California, USA) incremental measuring device (precision of $0.01 \mathrm{~mm}$ ), on two radii taken from the basal cross sections. The two radii were then cross dated using pointer years and graphical plots to identify incomplete rings or errors in dating. The same procedure was applied to all samples of each species, and each chronology was corrected for missing rings or dating errors. Cross-dating accuracy was verified using the COFECHA program (Holmes 1983). A mean chronology was then constructed for each species. Each ring-width series was divided by its mean in order to give the same weight to each tree without disturbing either long- or short-term signals. Individuals with atypical growth or without good cross dating were not included in the mean chronology. Dead stems were precisely dated by cross dating with the mean chronology.

Individual chronologies were used to study the frequencies of sharp increases and decreases in growth (Bergeron and Brisson 1990). Following criteria defined by Lorimer (1980) and Glitzenstein et al. (1986), a tree was considered to show a significant, sharp release in its growth if (a) for trees under suppression (ring width $<1 \mathrm{~mm} /$ year prior to the year under study) ring width at least doubled over a 3 -yr period, and growth for the $10 \mathrm{yr}$ after the initial increase averaged at least twice that of the preceding $10 \mathrm{yr}$, or (b) for trees presumably not suppressed, ring width increased by at least $50 \%$ over a $3-y r$ period, and this increase was maintained for $10 \mathrm{yr}$ as in (a). A sharp decrease in growth was defined as a $50 \%$ decrease in ring width for non-suppressed trees and $25 \%$ for suppressed trees. A 5-yr growth reduction was used instead of $10 \mathrm{yr}$ for dead fir because the number of rings present following the last growth decrease was often limited.

In order to synthesize the data and to reduce space the results of the dendroecological analyses are generally presented for all stands put together. However, results for individual stands are available in electronic format in the Appendix. 


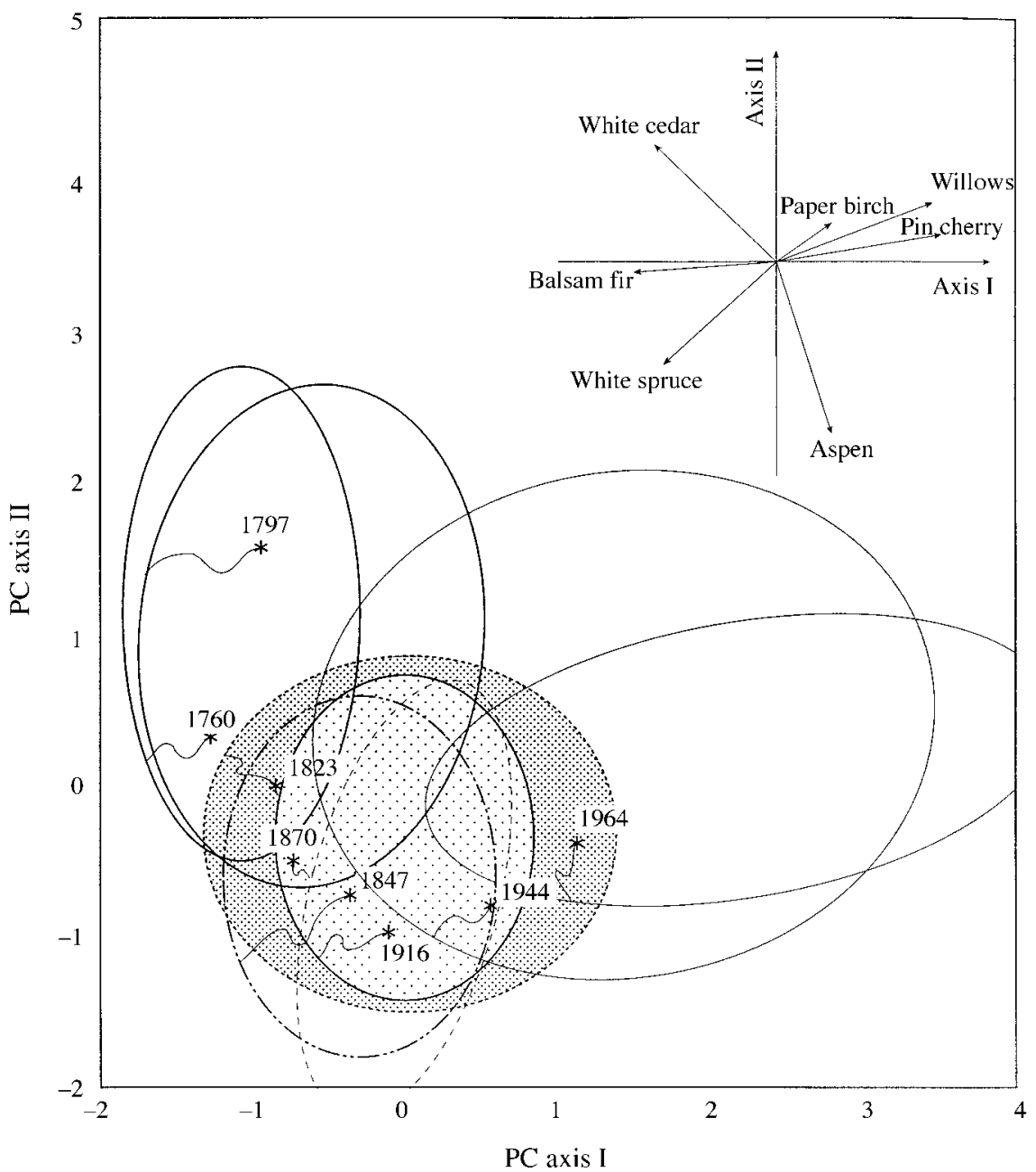

FIG. 2. Principal-components (PC) analysis based on tree species basal areas. Species vectors associated with the two first axes are shown in the upper portion of the figure. Concentration ellipses including $80 \%$ of stands from a specific fire year are depicted. In each concentration ellipsis the site used for a detailed dendroecological analysis is represented by an asterisk.

\section{RESUlts}

\section{Stand composition}

The principal-components analysis shows $22.5 \%$ and $17.3 \%$ of the variance in stand composition to be found on the first and second axes, respectively. The first axis (Fig. 2) discriminates early successional post-fire species to the right from late-successionnal species to the left. The second axis is mainly characterized by trembling aspen and white spruce vectors. Stand ordination (Fig. 2) shows a gradual clockwise transition from early post-fire stands, located in the upper right part of the diagram, toward old stands located in the upper left. This transition is associated with the presence of pin cherry (Prunus pensylvanica and willows (Salix) spp.) in very young stands (26 and $56 \mathrm{yr}$ ), aspen in young stands (74 and $120 \mathrm{yr}$ ), balsam fir and white spruce in mid-aged stands (143 and $167 \mathrm{yr}$ ), and eastern white cedar in the oldest stands (193 and $230 \mathrm{yr}$ ).
There is a great deal of variability in stand composition with stand age as expressed by stand dispersion in the ordination diagram. Variability is particularly high in early post-fire stands and appears to decrease with time. The variability observed in the oldest stands is mostly explained by the low abundance of white cedar in some stands while balsam fir is present everywhere. With the exception of the 1870 stand, the stands used for the demographic studies are all included in the ellipse representing $80 \%$ of the variability around the centroid.

Regressions showing changes in species basal area with time since fire are presented in Fig. 3. Willows and pin cherry are only important in the first $26 \mathrm{yr}$ following fire. Aspen is responsible for an important part of stand basal area in the first $167 \mathrm{yr}$ following fire but its importance decreases afterwards. Paper birch's presence is significant throughout succession although its greatest basal-area values occur in the youngest and oldest stands. White spruce basal area starts to be important 


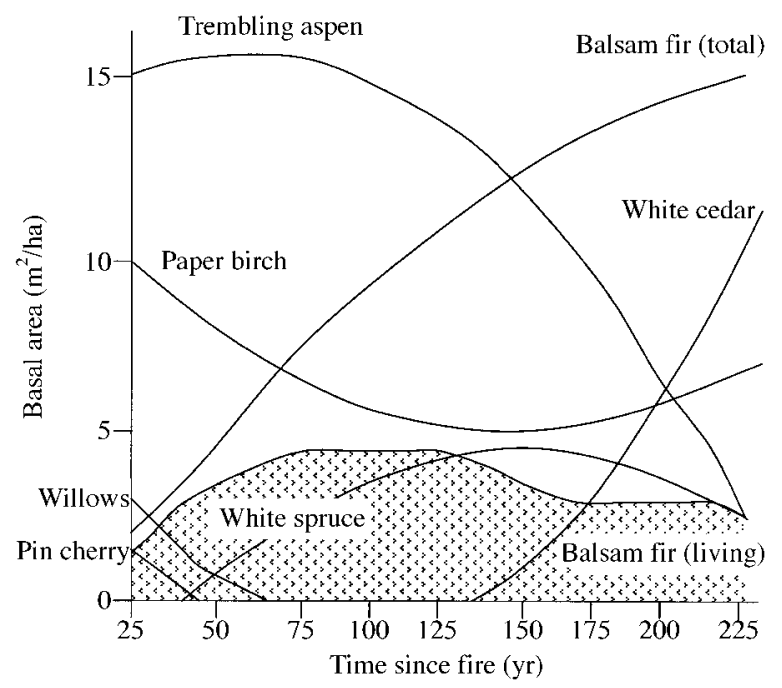

FIG. 3. Polynomial regressions of species basal areas for all stands in relationship to time since fire. All regressions are significant at $P<0.05$ with the following $R^{2}$ : aspen (0.15), total balsam fir (0.32), paper birch (0.05), white spruce (0.11), pin cherry, (0.16), willows (0.19), and white cedar (0.39). The stippling shows the basal area for living balsam fir.

74 yr after fire, peaks $143-167$ yr after fire, and decreases afterwards. Total balsam fir basal area (living and dead stems) increases throughout succession. However, because mortality is greatest in the oldest stands living basal area tends to decrease. The proportion of basal area accounted for by white cedar is important only in the 193 and 230-yr-old stands.

\section{Pre-fire composition}

Except for the 1760 fire, the presence of snags and/ or logs has allowed me to date the previous fire in all stands used for the dendroecological reconstructions. All stands very likely originated following fires in 1717 or 1760 (Table 2 and Fig. 1). In some cases, trees older than those fires were observed but because the pine snags were younger I assume that these older trees survived the fire. Intervals between two successive fires vary from 37 to $224 \mathrm{yr}$.
TABLE 2. A list of the sampled dead trees used to determine the date of the fire preceding the last recorded fire for each stand used in the detailed dendroecological analysis.

\begin{tabular}{|c|c|c|c|}
\hline Last fire & $\begin{array}{c}\text { Previous } \\
\text { fire } \dagger\end{array}$ & $\begin{array}{c}\text { Interval } \\
(\mathrm{yr})\end{array}$ & Individual trees sampled \\
\hline 1964 & 1760 & 204 & $\begin{array}{l}\text { jack pine: }<1771,1764, \\
\text { 1765, }<1770,1768,1767 \\
<1805,<1770,<1767 \\
\quad<1778,1766,<1777 \\
1770,1771,1774\end{array}$ \\
\hline 1944 & 1717 & 223 & $\begin{array}{l}\text { jack pine: }<1779,<1765 \\
\quad<1756,<1744,<1740 \\
\quad<1763,<1757\end{array}$ \\
\hline 1916 & 1717 & 199 & $\begin{array}{l}\text { jack pine: }<1731,<1746 \\
\quad<1729,<1762,<1739 \\
\text { cedar: }<1766,<1706 \\
\quad<1771,1766,<1745 \\
\quad<1752\end{array}$ \\
\hline 1870 & 1760 & 110 & $\begin{array}{c}\text { jack pine: }<1771,1768 \\
1770,<1770,1772 \\
<1777,1770,<1775\end{array}$ \\
\hline 1847 & $\begin{array}{l}1717 \text { or } \\
\text { older }\end{array}$ & 130 & $\begin{array}{l}\text { jack pine: }<1718,<1741 \text {; } \\
\text { cedar: } 1685,1671,1739 \text {, } \\
1694\end{array}$ \\
\hline 1823 & 1760 & 63 & $\begin{array}{l}\text { jack pine: }<1730,<1729 \\
\quad(\text { scar: } 1760)\end{array}$ \\
\hline 1797 & 1760 & 37 & cedar: $<1780$ \\
\hline 1760 & $?$ & $?$ & \\
\hline
\end{tabular}

$\dagger$ Most likely date according to the age of the oldest trees and the adjacent fire as presented in Fig. 1.

Using logs and stumps from trees that very likely recruited before the last fire, it is possible, in some cases, to assess pre-fire stand composition. The interpretation, however, is complicated by the fact that, except for white cedar, decay rates of the other species are fast and stems are datable for only a few decades following their death (Bergeron and Charron 1994). White cedar stems pre-dating the last fire were observed in the 1797, 1847, 1916, and 1944 stands suggesting that this species was present in the pre-fire stands (Table 3 ). The presence of white cedar in the pre-fire composition is congruent with the present composition of old-growth stands that were spared by these fires (Fig. 3). No stems from the pre-fire forest can be clearly identified in the 1823 and 1870 stands; only large dead aspen stems were observed, however, some

TABLE 3. Number of living and dead stems $(>5 \mathrm{~cm}$ in diameter at breast height) from the pre-fire and the post-fire cohorts for each stand.

\begin{tabular}{|c|c|c|c|c|c|c|c|c|c|c|}
\hline \multirow[b]{2}{*}{ Fire date } & \multicolumn{2}{|c|}{ Balsam fir } & \multicolumn{2}{|c|}{ White birch } & \multicolumn{2}{|c|}{ White spruce } & \multicolumn{2}{|c|}{ Trembling aspen } & \multicolumn{2}{|c|}{ White cedar } \\
\hline & Pre-fire & Post-fire & Pre-fire & Post-fire & Pre-fire & Post-fire & Pre-fire & Post-fire & Pre-fire & Post-fire \\
\hline 1964 & $1(1)$ & 0 & $1(1)$ & 0 & 0 & 0 & $5(4)$ & 112 & 0 & 0 \\
\hline 1944 & $1(5)$ & 2 & 1 & 20 & $1(2)$ & 1 & 0 & 105 & 13 & 0 \\
\hline 1916 & 1 & 55 & 1 & 24 & 0 & 16 & 0 & 31 & 14 & 0 \\
\hline 1870 & 0 & 1 & 0 & 1 & 0 & 3 & 0 & 25 & 0 & 0 \\
\hline 1847 & 0 & 5 & 0 & 21 & 0 & 5 & 0 & 1 & 4 & 0 \\
\hline 1823 & 0 & 1 & 0 & 5 & 0 & 1 & 0 & 17 & 0 & 0 \\
\hline 1797 & 0 & 2 & 0 & 16 & 0 & 0 & 0 & 0 & (3) & 5 \\
\hline 1760 & 0 & 0 & 0 & 1 & 0 & 3 & 0 & 0 & 0 & 5 \\
\hline
\end{tabular}

Notes: The post-fire cohort includes trees that germinated during the first $20 \mathrm{yr}$ following the fire. For the pre-fire composition, living trees that survived the fire are indicated in parentheses. 

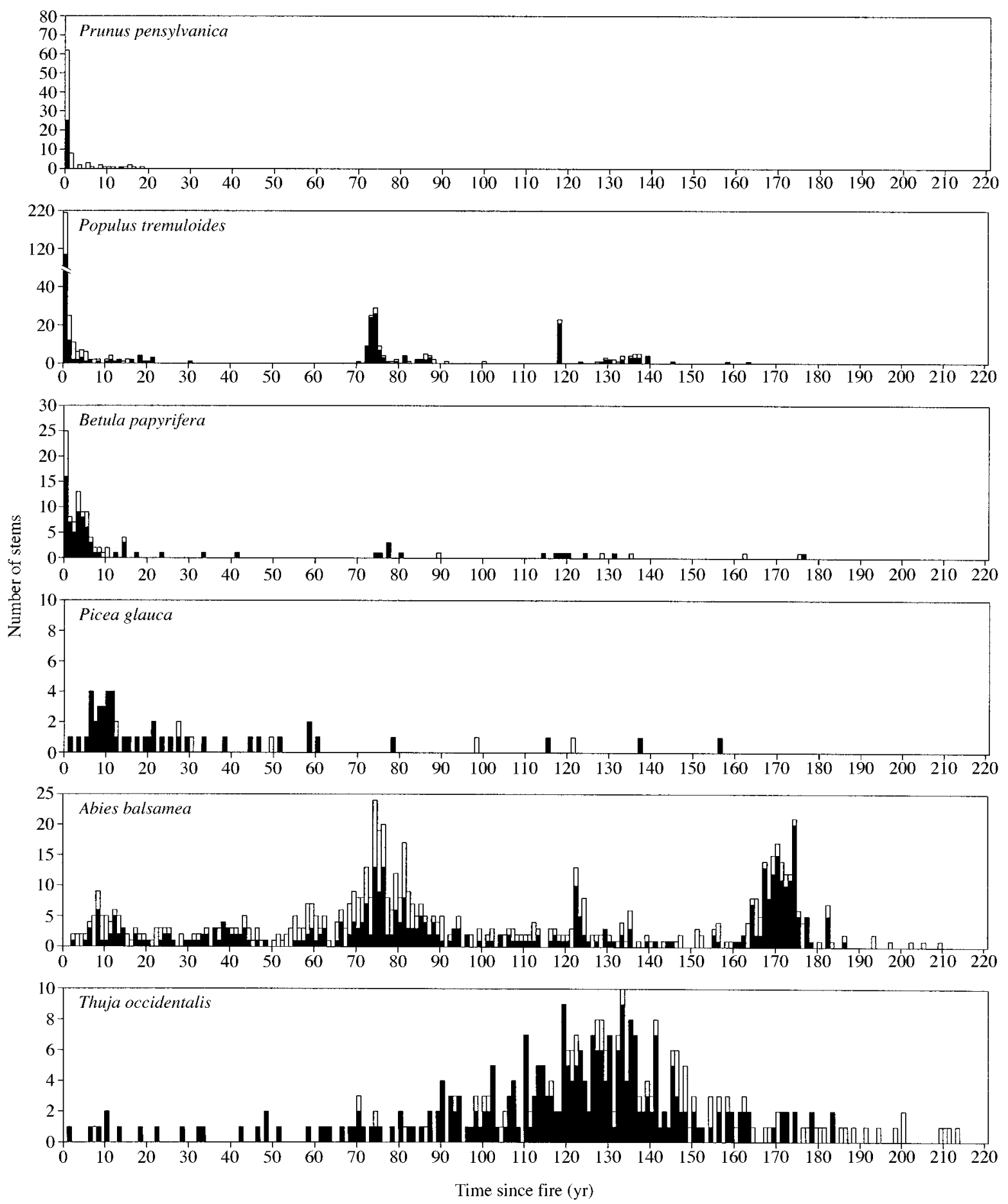

FIG. 4. Combined age structures for the eight stands taken together. Results include number of living (solid bars) and dead (open bars) stems $>1 \mathrm{~m}$ in height in relationship to time since fire.

of these might have a pre-fire origin. A pre-fire composition, dating back to the 1717 or 1760 fire, dominated by aspen would be congruent with the present composition of stands of the same age (63 and $110 \mathrm{yr}$ old) (Fig. 3). In the 1964 stand the presence of living scarred aspen and fir individuals together with a few large dead aspen stems suggests a mixed composition probably dominated by aspen. The low number of prefire stems observed despite the short period of time since fire might be an indication that this stand, which is located close to an area used for agriculture since the 1930s, was logged before it burnt. 
TABLE 4. Frequency and density of seedlings $(<1 \mathrm{~cm}$ in diameter at breast height) for the principal species, by stand age.

\begin{tabular}{|c|c|c|c|c|c|c|c|c|c|c|c|}
\hline \multirow[b]{2}{*}{$\begin{array}{l}\text { Stand } \\
\text { age }\end{array}$} & \multicolumn{2}{|c|}{ Balsam fir } & \multicolumn{2}{|c|}{ White birch } & \multicolumn{2}{|c|}{ White spruce } & \multicolumn{2}{|c|}{ Trembling aspen } & \multicolumn{2}{|c|}{ White cedar } & \multirow{2}{*}{$\begin{array}{c}\text { Total } \\
\text { density } \\
\text { (no./ha) }\end{array}$} \\
\hline & $\begin{array}{c}\text { Freq. } \\
(\%)\end{array}$ & $\begin{array}{l}\text { Density } \\
\text { (no./ha) }\end{array}$ & $\begin{array}{c}\text { Freq. } \\
(\%)\end{array}$ & $\begin{array}{l}\text { Density } \\
\text { (no./ha) }\end{array}$ & $\begin{array}{c}\text { Freq. } \\
(\%)\end{array}$ & $\begin{array}{l}\text { Density } \\
\text { (no./ha) }\end{array}$ & $\begin{array}{c}\text { Freq. } \\
(\%)\end{array}$ & $\begin{array}{l}\text { Density } \\
\text { (no./ha) }\end{array}$ & $\begin{array}{c}\text { Freq. } \\
(\%)\end{array}$ & $\begin{array}{l}\text { Density } \\
\text { (no./ha) }\end{array}$ & \\
\hline 26 & 40 & 4385 & $\cdots$ & $\ldots$ & 20 & 198 & 60 & 1833 & $\ldots$ & $\ldots$ & 6417 \\
\hline 46 & 90 & 6255 & 25 & 657 & 31 & 813 & 41 & 993 & 4 & 82 & 8965 \\
\hline 74 & 100 & 17970 & 38 & 775 & 74 & 959 & 24 & 941 & 36 & 898 & 21582 \\
\hline 120 & 98 & 11988 & 29 & 556 & 57 & 1150 & 48 & 1447 & $\ldots$ & $\ldots$ & $15 \quad 145$ \\
\hline 143 & 100 & 38090 & 65 & 5357 & 81 & 7481 & 58 & 1169 & 8 & 124 & 52543 \\
\hline 167 & 98 & 23295 & 43 & 992 & 64 & 1390 & 55 & 1974 & 17 & 573 & 28586 \\
\hline 193 & 100 & 19519 & 65 & 2892 & 65 & 1556 & 24 & 282 & 59 & 2430 & 26679 \\
\hline 230 & 96 & 15960 & 27 & 660 & 29 & 677 & 38 & 1147 & 54 & 3328 & 21772 \\
\hline
\end{tabular}

Note: Frequency is defined as the percentage of the studied quadrats in which seedlings were found.

\section{Post-fire composition}

Aspen is present in the post-fire cohort of all stands up to 1823 (Table 3). Aspen trees recruited long after fire were also observed in the 1760 and the 1797 stands, suggesting that aspen was also present in the post-fire cohort of these older stands but that its remains have disappeared. White birch recruited following fire in all stands. Although less abundant, balsam fir and white spruce are also present in the post-fire cohort of almost all stands. On the other hand, despite its presence in the pre-fire composition of many of the stands, white cedar was recruited in the post-fire cohort only in the 1797 and 1760 stands.

\section{Age structure}

In order to show the overall trends, results are presented for all stands put together (Fig. 4). The age structures include only stems $>1 \mathrm{~m}$ in height and are presented in relationship to time elapsed since fire rather than calendar date.

With the exception of cedar all species show a peak in recruitment just after fire. While pin cherry is recruited only during the first $20 \mathrm{yr}$ following fire, small numbers of aspen are present even a long time after fire. These lower peaks in recruitment occur over long periods and may be a response to canopy gaps created by the gradual dismissal of the post-fire cohort. Following an important post-fire peak, a low but constant recruitment of white birch is also observed.

Compared to the deciduous species the post-fire recruitment of white spruce and balsam fir is delayed for 5-10 yr. Following an initial peak, recruitment of white spruce is constant but very low and very few stems are recruited into the canopy. Balsam fir on the other hand is constantly and abundantly recruited with important peaks centered $10,75,125$, and $170 \mathrm{yr}$ after fire. Peaks in recruitment are roughly synchronous with similar peaks in aspen and white birch, suggesting that they may be associated with similar causes.

Although present in low abundance in the post-fire cohort, white cedar recruitment increased dramatically between 70 and $130 \mathrm{yr}$, declining afterward.

The observed patterns of recruitment are congruent with the changes in species dominance observed in Fig. 3. Decreases in pin cherry, willow, aspen, and white birch are linked to lower recruitment in those species between fire events. In contrast, the constant recruitment of balsam fir and the late arrival of white cedar are responsible for their dominance a long time after fire. White spruce's maximum basal area observed at midsuccession is not explained by a late peak in establishment but by slower growth under the deciduous canopy and late recruitment to the canopy. A great longevity and constant but low recruitment of white spruce and white birch ensure their presence in old-growth stands.

\section{Stand regeneration}

Except for the 26-yr-old stand, regeneration is dominated by balsam fir (Table 4). It increases in abundance in the first $167 \mathrm{yr}$ after fire and decreases afterwards. Although less abundant, white spruce regeneration follows a similar pattern. White cedar seedlings are abundant only in the older stands although their frequency of occurrence is low $(\sim 50 \%)$. Seedling age structures for the three coniferous species (Appendix: Fig. 2) showed a constant recruitment and seedlings of all ages up to $40 \mathrm{yr}$ were observed. In the case of white cedar $>50 \%$ of the seedlings originated from vegetative layering. With the exception of the 1964 fire, birch seedlings and aspen root suckers are present in stands of all ages. Very few, however, survive more than one year (Appendix: Fig. 2).

\section{Species life-span and mortality}

The oldest aspen that were found in the sampled quadrats are $\sim 90$ yr old (Fig. 5). However, the lack of dead, old individuals suggests that none of our sample stands have recently experienced a peak in overstory mortality and that consequently aspen longevity in this area might be longer than 90 yr. In fact, by searching the forest around our quadrats we were able to find a few trees that were $>150$ yr old.

The oldest balsam fir was $>150$ yr old when it died. In fact, $59 \%$ of the balsam fir stems collected were dead and no living trees were older than 110 yr. Dead stems are well distributed throughout all age classes, 

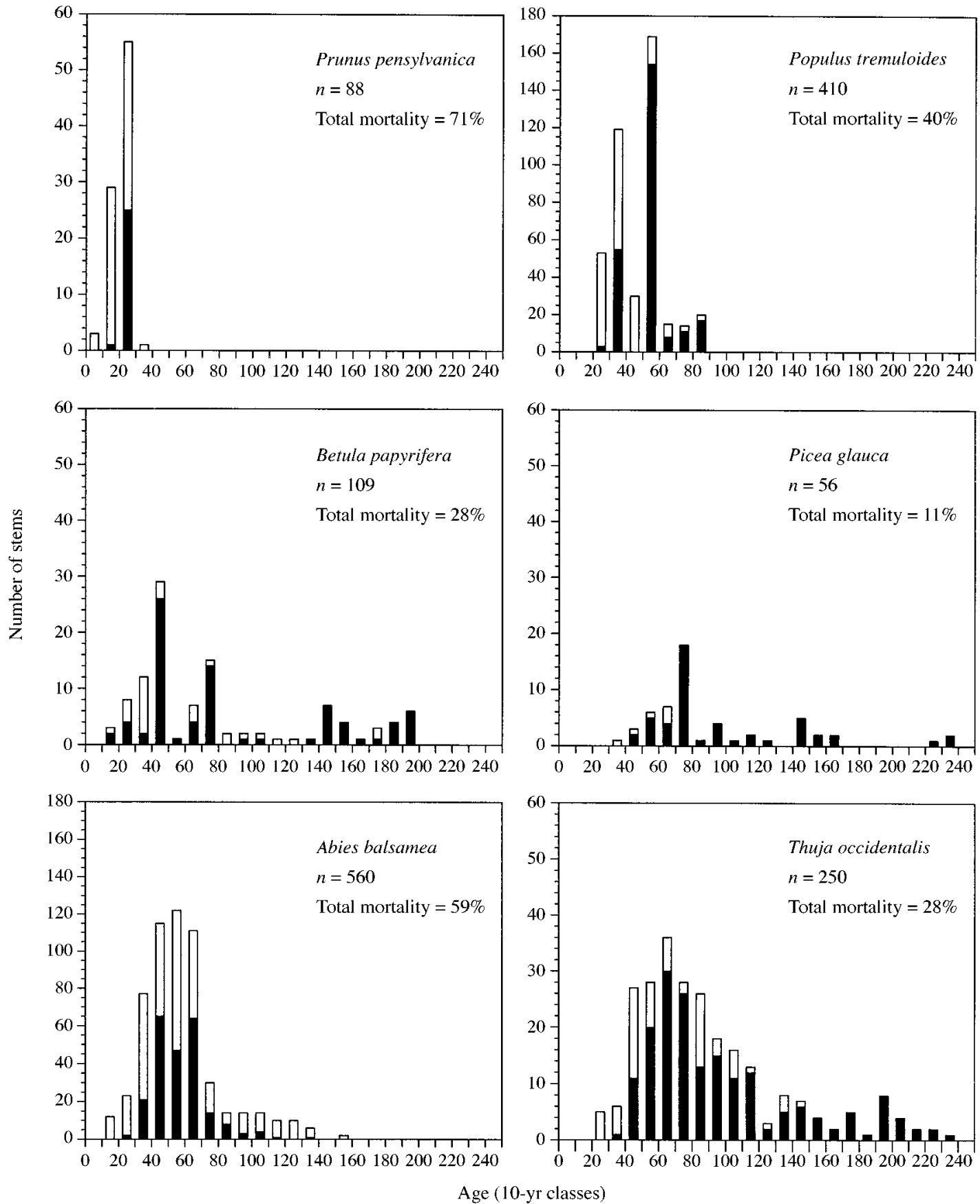

FIG. 5. Distribution of living (black bars) and dead (open bars) stems per species by age class, all stands combined ( $n$ $=$ total number of stems per species).

with a slight increase in the oldest age classes. The high number of dead stems observed is, at least in part, due to the recent (1972-1987) spruce budworm outbreak (Bergeron et al. 1995). Mortality is concentrated in this period in all stands and peaks early in the 1980s.

While pin cherry's longevity is typical of an early successional species, with no stems $>40 \mathrm{yr}$ old, white birch can reach $200 \mathrm{yr}$ of age. Cumulative birch mor- tality across all stands appears slightly higher in 1977, 1979, and 1980 (Appendix: Fig. 3). This mortality, which appears to be synchronous with balsam fir mortality, could be due to stress caused by the opening of the canopy following the spruce budworm outbreak.

White spruce and white cedar longevity is greater than the maximum age of all stands and these species show no sign of higher mortality in the oldest stands. Instead, 

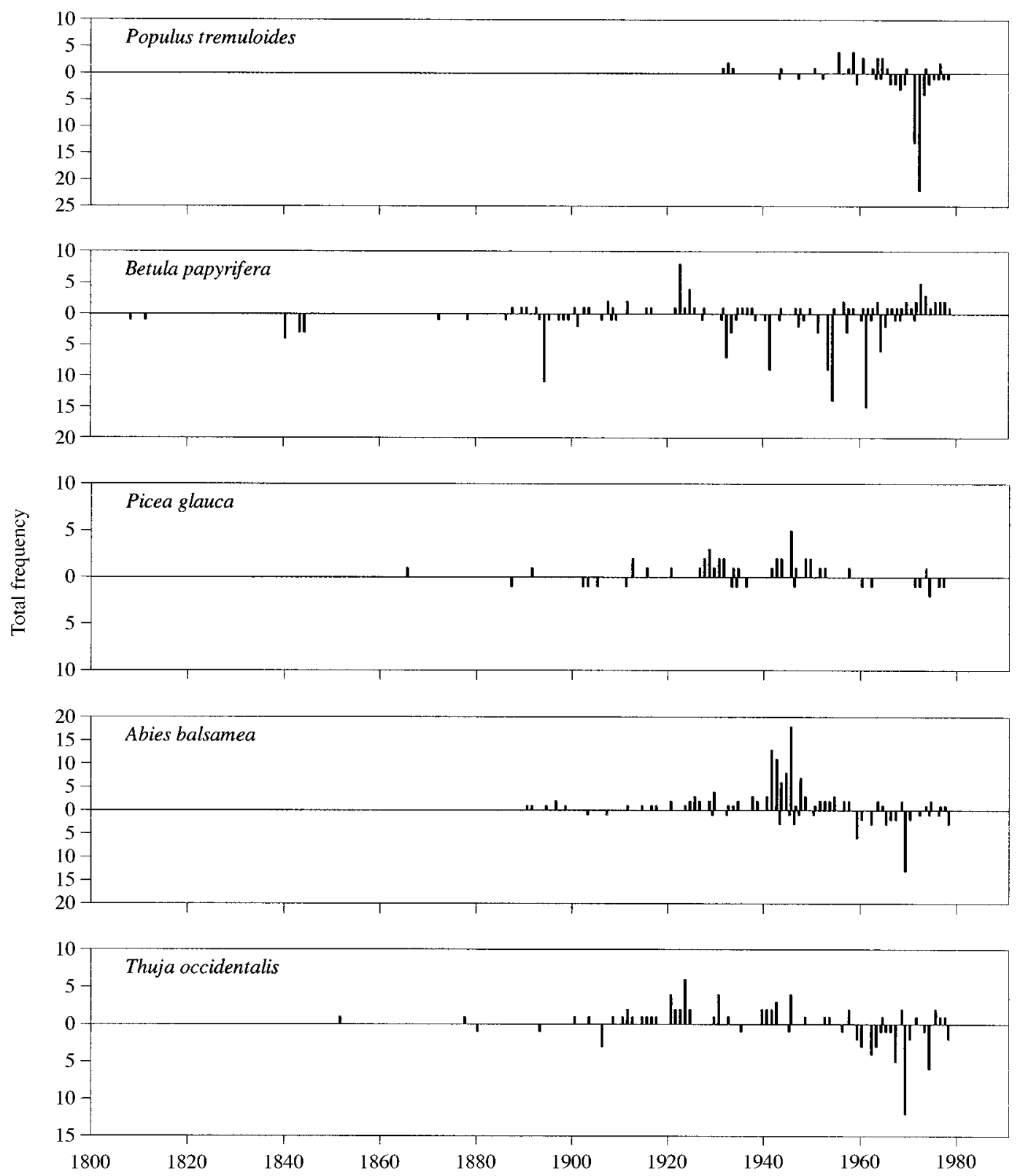

FIG. 6. Frequency of stems $>5 \mathrm{~cm}$ in diameter at breast height showing a sharp decrease or increase in radial growth. Results are presented per species across all stands for the period 1760-1990.

mortality appears limited to small stems in the case of spruce, as we found only one dead stem $>5 \mathrm{~cm}$. White cedar mortality is distributed across all age classes.

Overall, very little mortality was observed in white spruce (only $11 \%$ of total stems), whereas figures were higher for other species: white cedar $(28 \%)$, white birch $(28 \%)$, aspen $(41 \%)$, balsam fir (59\%), and pin cherry (71\%).

\section{Species growth and interaction}

Radial growth.-Ingeneral, a low frequency of growth releases and decreases was observed (Fig. 6).
White spruce, then paper birch, and then balsam fir are, respectively, the species that most frequently experienced periods of release. Growth releases were more rarely observed in white cedar and aspen. Except for paper birch, sharp decreases in radial increment are relatively infrequent. Patterns of release and decrease in growth appear to be influenced primarily by local stand development and/or insect outbreaks.

Aspen experienced frequent growth decreases during the 1964-1979 period with the strongest dip occurring in 1971-1972. This decrease might be due to severe 

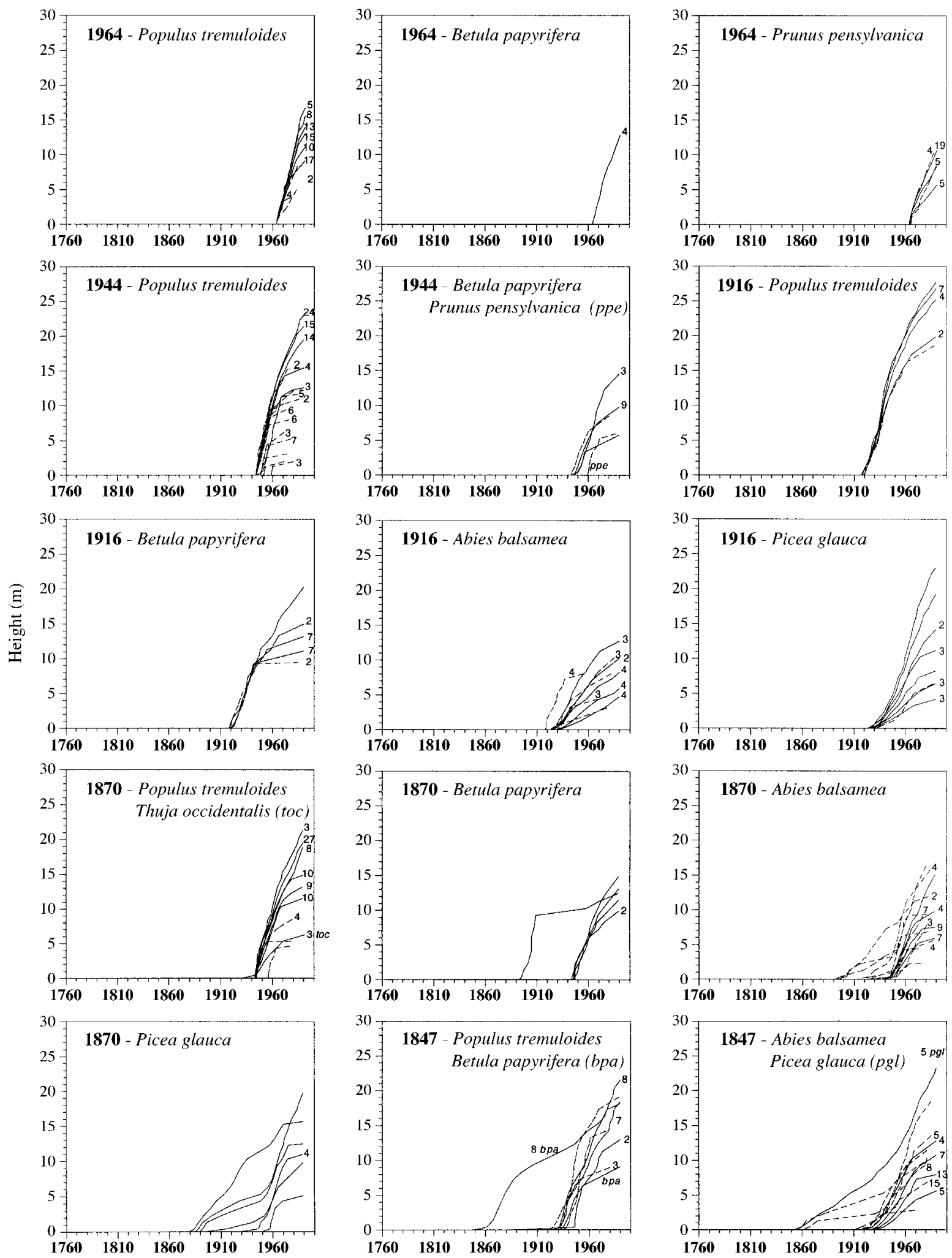

FIG. 7. Height growth increment for all stems $>1 \mathrm{~m}$ in height. Stems with similar height growth patterns were averaged, and their number is given on the graphs. Dashed lines indicate dead stems with truncated height growth. Results are presented per stand and per species for the period 1760-1990. (Fig. 7 continues on facing page.) 

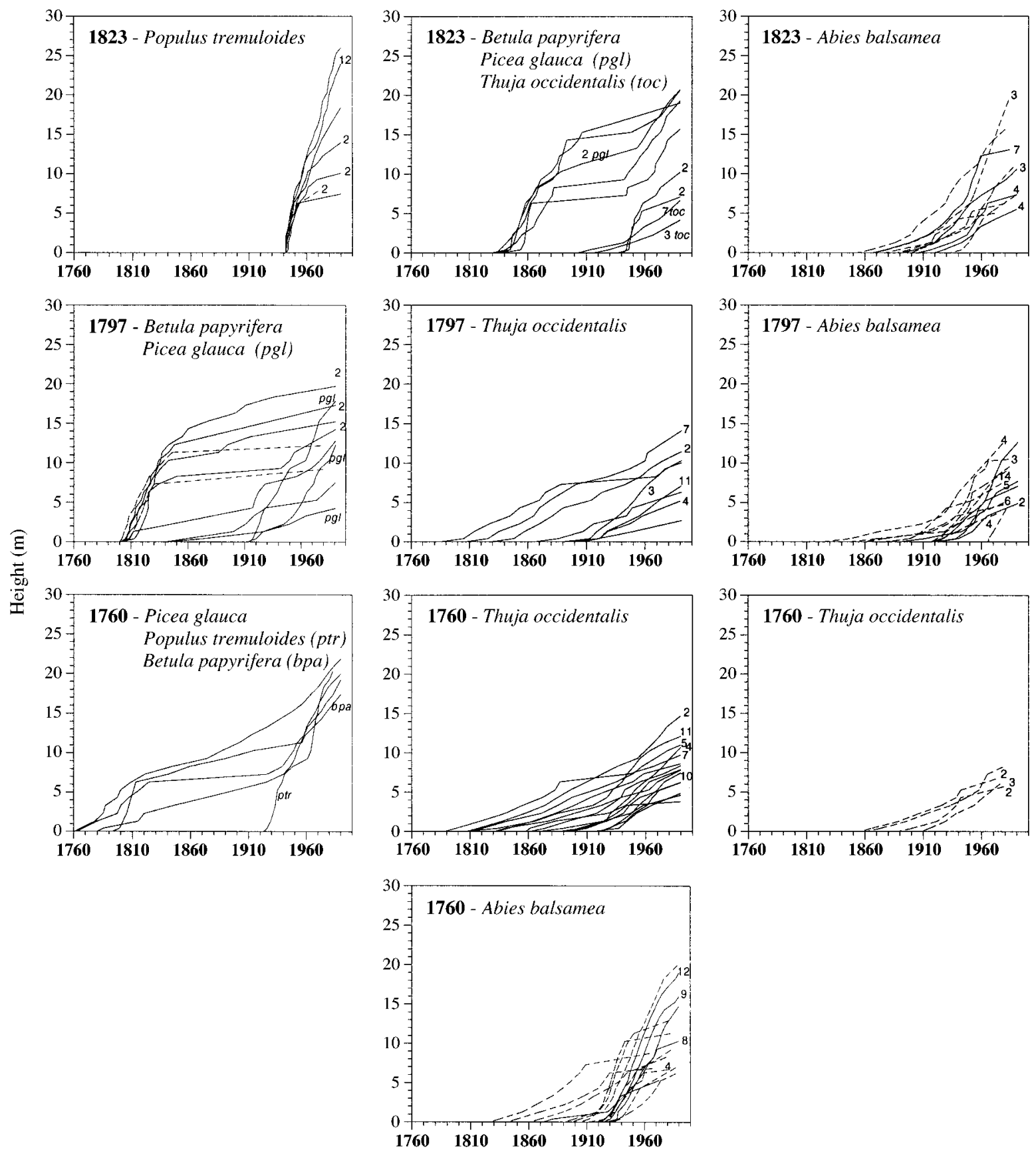

FIG. 7. Continued

tent caterpillar outbreaks that are frequently reported in the area (Martineau 1985).

White birch's growth increases in 1922 and 1924 are congruent with the recruitment of an aspen cohort in the 1847 stand (Appendix: Fig. 4) and may be due to a large opening in the canopy. Increases observed in other stands do not seem to match any specific event and are probably due to very local responses. Birch's growth decreases are abundant and more or less synchronous among stands, occurring in 1808, 1811, 1840,
1843-1844, frequently between 1872 and 1909 with a strong dip in 1894, and again between 1927 and 1971 with dips in 1932, 1941, 1953-1954, and 1961.

Sharp growth increases observed in balsam fir and white spruce are synchronous with massive aspen recruitment in the 1870, 1847, and 1823 stands (Appendix: Figs. 4 and 5). The presence of sharp growth increases around 1930 in the 1760 and 1797 stands can also be associated with a peak in balsam fir recruitment (Appendix: Figs. 4 and 5). More or less synchronous 
sharp decreases were observed for these two species around 1905, 1935, 1945, and between 1960 and 1980 . The last and most frequently observed decreases preceded the widespread fir mortality caused by the last spruce budworm outbreak in the area, suggesting that this decrease and possibly the preceding ones may be due to defoliation by the spruce budworm.

Growth increases in white cedar were frequently observed between 1910 and 1940. As with fir and spruce, growth decreases in cedar were also more frequent between 1960 and 1980.

Height growth. Aspen height growth is typical of a shade-intolerant species: trees reach the canopy or die early. This pattern is well illustrated by the stand structure in the 1964 and 1944 stands (Fig. 7), where dominant trees overtop suppressed or dead stems. A single canopy layer characterizes the 1916 stand where mature and very tall $(>25 \mathrm{~m})$ aspen are observed. A more discontinuous canopy layer in the older stands allows for the presence of vigorous aspen of various heights.

Few paper birch and white spruce reach the canopy immediately after fire; instead most of them are suppressed and are maintained in the sub-canopy layer for periods that may exceed $150 \mathrm{yr}$. Although white spruce can reach heights comparable to aspen, paper birch is generally shorter than aspen. In stands recruited following recent fires, birch is rarely taller than $15 \mathrm{~m}$ in height whereas aspen may be greater than $25 \mathrm{~m}$ (see the 1964, 1944, and 1916 stands). Height growth of birch was reinitiated in the older stands, probably following the more or less synchronous mortality of the first aspen cohort (see the 1847,1870 , and 1823 stands) or due to the non-synchronous mortality of a few individuals (see the 1797 and 1760 stands). The regular growth pattern observed for many birch and spruce stems in the 1797 stand suggests that they were growing immediately after fire in the absence of aspen in this stand.

In comparison to birch, which is generally taller than $10 \mathrm{~m}$, very shade-tolerant spruce and fir can remain in the lower canopy for long periods. In most cases a long period of suppression is followed by an abrupt reinitiation of height growth that is often followed by another period of suppression. With the exception of the 1760 stand, balsam fir rarely reaches the highest canopy layer. White cedar has a low but constant height growth in the sub-canopy, although it rarely exceeds $15 \mathrm{~m}$.

\section{DISCUSSION}

\section{Individual species dynamics}

Species dynamics are controlled by species shade tolerance and their means of regeneration. Although all deciduous tree species are able to invade burnt area from seeds, vegetative propagation is the most common strategy (Zasada et al. 1992). Exceptions are willows and pin cherry, which are not present in mature stands and thus must reinvade burnt stands, respectively, from seeds dispersed over long distances and long-lasting seed banks (Marks 1974). Following fire there is a massive and immediate regeneration of aspen root suckers, however, factors leading to the recruitment of subsequent cohorts are not as easily identified. Since the stands were not logged and there are no reports of pests causing stand-level dieback of trembling aspen, the gradual dismissal of the first cohort has to be invoked to explain the recruitment of the second cohort. When a large aspen dies, the newly created gap cannot easily be filled by the advance growth of other species. Even when such advance regeneration is abundant it will not usually grow with sufficient speed to outcompete fast-growing aspen root suckers. In many cases root suckers are already present in the regeneration layer (Kneeshaw and Bergeron 1996, Table 4). Aspen recruitment may also be enhanced by the group tree mortality observed in hardwood stands of this area (Kneeshaw and Bergeron 1998). Overmature aspen stands, often made of a few clones (Barnes 1966), may deteriorate very rapidly_ias short a time as 6 yr (Shields and Bockheim 1981).

Birch's recruitment pattern resembles aspen's but at lower densities. Seedlings and saplings are observed in all stands and are recruited in gaps created by either aspen or fir mortality (Kneeshaw and Bergeron 1998). Following establishment birch tends to persist in all stands for a very long period due to both its longevity (many birch in this study exceeded $230 \mathrm{yr}$ of age) and its capacity to resprout when the main stem, recruited as part of the post-fire cohort, died and was replaced by a new sprout from the same individual (personal observation). These characteristics may also partially explain the presence of paper birch in old-growth forests in Minnesota, as reported by Frelich and Reich (1995).

Fir is also present in the post-fire cohort, but maximum recruitment, as with white spruce, is delayed for $\sim 5$ yr. Similar delays have been observed for other species that rely on seeds for post-fire establishment (Sirois and Payette 1989, Bélanger et al. 1993, Bergeron and Brisson 1994). Many factors may be responsible for this delay, including low seed production at the time of disturbance, and/or inadequate seedbeds during the first few years after fire. Underestimation of tree age due to absent or false rings or the failure to reach the stem collar have also been used to explain apparent delays in regeneration (DesRochers and Gagnon 1997). However, because cross sections were taken at the very base of the trees and ring series were carefully cross dated, I do not believe the delay to be an artifact of the sampling procedure. Maximum fir recruitment occurred concurrently with the dismissal of the first aspen cohort approximately $70 \mathrm{yr}$ after fire. Subsequent recruitment is probably linked to openings created by spruce budworm outbreaks that occurred throughout the 20th century (Morin et al. 1993). Outbreaks kill mature trees but generally do not affect the seedling bank, from which the new overstory cohort will be recruited (Morin 1994). The budworm-caused mortality rate increases with the abundance of fir and 
is more severe in mature than in immature stands (MacLean and Ostaff 1989). Since mature fir increases in abundance with time since fire, mortality and subsequent recruitment are also more important in the older stands. During the 1972-1987 outbreak $>70 \%$ of the fir in the coniferous forest died (Bergeron et al. 1995), creating gaps averaging $370 \mathrm{~m}^{2}$ (Kneeshaw and Bergeron 1998). A concentration of trees $\sim 60$ yr old (Fig. 5) and the lack of old fir, although the species attain an age of $150 \mathrm{yr}$ (Sims et al. 1990), suggests that most of the trees were recruited following the 19191929 outbreak (Morin et al. 1993). This would be congruent with regeneration peaks observed around 1930 in the older stands (1760 and 1797). Although most important following large canopy disturbances, the constant recruitment observed with time since fire suggests that fir regenerates continuously in smaller gaps (Frelich and Reich 1995).

White spruce canopy recruitment is limited mainly to the post-fire cohort, and subsequently is very low. Mortality due to the spruce budworm was observed to be very low (Bergeron et al. 1995), thereby permitting most spruce individuals to survive to an old age. Poor recruitment following canopy disturbances other than fire appears to be related to the absence of disturbance to the soil. Spruce's small seeds, in comparison to those of balsam fir, may limit its establishment on substrates other than mineral soil or recently burned organic soils (Zasada et al. 1992). Large areas of windthrow following outbreaks, although described elsewhere (Morin 1990), were not observed in this region. Trees killed by the spruce budworm die standing and remain that way until they break near the base of the trunk due to root and trunk rots (Bergeron et al. 1995). This lack of soil disturbance may explain why I did not observe an increasing abundance of white spruce following spruce budworm outbreaks as reported for some sites in Ontario and Québec (Ghent et al. 1957). Seedlings mortality is, however, very low and thus may permit a slow but continuous recruitment of white spruce in oldgrowth stands.

Despite its abundance in the surrounding older forest, the very low constancy of white cedar in the postfire cohort may possibly be related to its lower seeddispersing capability (Sims et al. 1990). White cedar is generally a sub-canopy tree, in comparison to white spruce and balsam fir. An alternative hypothesis would be the absence of adequate seedbeds after fire. Scott and Murphy (1987) and Simard et al. (1998) have shown the importance of decaying wood and a mossy ground cover for Thuja establishment, and De Grandpré et al. (1993), working in similar stands, described an increase in the moss layer throughout succession. Cedar's establishment peak occurs some decades after the dismissal of the post-fire cohort, which very likely corresponds with an increase in the dead-wood component on the ground. The explosive pattern of recruitment that follows may be explained by the intense layering favored by the more humid conditions found under a conifer canopy. Cedar's exceptional longevity (Archambault and Bergeron 1992), combined with its shade tolerance and its resistance to insects and pathogens (Sims et al. 1990), ensures not only its maintenance but also its increasing abundance in the absence of fire.

\section{Stand dynamics}

Stand dynamics can be characterized by three important stages of development: (1) the post-fire cohort dominated by hardwoods, (2) the dismissal of the first aspen cohort (aspen stand breakup) and the recruitment of subsequent cohorts of aspen dominated by mixed woods and, (3) spruce budworm outbreaks in which stands are increasingly dominated by coniferous species.

As suggested by Palik and Pregitzger (1991), the relative importance of each species in the post-fire cohort appears to be controlled more by initial numbers than by different niches. Because of abundant root suckers aspen easily saturates most of the safe sites. Sprouting or seeding of birch is also abundant and this species dominates in the absence of aspen. Delays in conifer regeneration and their slower growth explain their relatively low abundance in the post-fire cohort. However, in the absence of birch and aspen, pure postfire stands of conifers may be observed (Paré and Bergeron 1996). Variations in the abundance of different species in the post-fire cohort can have a large impact on subsequent stand development. The proportion of deciduous trees to conifers affects the success of subsequent cohorts of deciduous species, as well as of conifer regeneration. Many studies have shown the inhibitory effects of deciduous litter on conifer establishment (Zasada et al. 1992, Simard et al. 1998) and thus dominance by deciduous trees may retard conifer invasion.

A large variation in the initial post-fire composition as observed in Fig. 2 may be linked to different prefire compositions, proximity of seed sources (Galipeau et al. 1997), and variations in fire severity (Johnson 1992). Pre-fire composition does not seems to be the determining factor in this area as deciduous species return as principal components in the post-fire cohort even when old-growth conifer stands have burnt. Experimental cutting in a 230 -yr-old coniferous forest has shown that a few mature aspen trees per hectare can produce a sufficient number of root suckers to regenerate a pure aspen stand (Lavertu et al. 1994). This contrasts with fire-dependent jack pine, which may become locally extinct during long fire intervals (Bergeron and Dansereau 1993, Frelich and Reich 1995). Explaining variations observed in post-fire composition is beyond the scope of this paper and I will therefore concentrate here on the most typical stand succession beginning with aspen as the dominant species.

Once trees are established, stand development is con- 
trolled by differential growth among the species present. The observed delay in the period of maximum post-fire recruitment may explain in part why balsam fir and white spruce are mainly concentrated in the subcanopy layers. But even without a delay it is reasonable to believe that the genetically controlled patterns of height and diameter growth favor aspen over all other species (Zasada et al. 1992). Growth differences between aspen and paper birch have been further accentuated by the presence of important and synchronous growth reductions in birch. Bergeron and Charron (1994) associated this phenomenon with the presence of forest tent caterpillar outbreaks, but crown dieback of birch following poor climatic conditions has also been reported (Braathe 1995).

The next important step in stand development is the dismissal of the aspen cohort. Birch, fir, and white spruce, which established mainly after fire, can now be recruited into the canopy layer. Large openings created by the death of aspens are also sufficient to recruit a new but smaller cohort of aspen. A decreased production of aspen root suckers with time may be linked to several factors: (1) smaller canopy gap that do not allow sufficient heat and light to arrive at ground level to stimulate suckering and/or to sustain growth (Burns and Honkala 1990), (2) an increase in the humus layer inhibiting aspen suckering (Lavertu et al. 1994), and (3) competition by other species already well established. At this stage, the structure of the stand usually changes from a matrix dominated by aspen to a mosaic of patches dominated by all four species. The same change in structure has been described for similar stands in the Great Lakes area (Frelich and Reich 1995).

As aspen decreases in number, stand dynamics are driven primarily by budworm-induced fir mortality. In addition to causing a cycling of fir (Morin 1994), outbreaks allow for some recruitment of deciduous species. However, outbreaks do not bring succession back to the deciduous stage, but on the contrary appear to contribute to dominance of the canopy layer by balsam fir and white cedar (Kneeshaw and Bergeron 1998). Old-growth stands are thus characterized by a continuous low-canopy layer of balsam fir and white cedar from which taller birch and white spruce individuals emerge. Aspen is only found as single individuals or in small patches probably associated with areas experiencing more severe outbreaks.

The observed successional process involving several successive cohorts of aspen is more complex than the simple replacement of hardwoods by more shade-tolerant species previously reported for the boreal and deciduous forests in eastern North America (Runkle 1981, Viereck 1983, Frelich and Reich 1995). In contrast, self-perpetuating aspen stands are common in the mixed boreal forests of western North America where shade-tolerant species are rare (Burns and Honkala 1990, Peterson and Peterson 1992). The abundance of aspen together with the lower levels of conifer regeneration than found further to the east or to the south may explain the intermediate situation observed in the Lake Duparquet area.

After $230 \mathrm{yr}$, stands are still mainly composed of trees originating from discrete events such as fire, dismissal of the first aspen cohort, or spruce budworm outbreaks. In fact, old stands are still recovering from large gaps created in the fir canopy by the most recent spruce budworm outbreaks (Bergeron et al. 1995). This dependence on relatively large and synchronous canopy disturbances contrasts with old-growth forests dominated by either black or Norway spruces where a quasi-equilibrium situation, maintained by small canopy disturbances, is often reported (Cogbill 1985, Hofgaard 1993, Kuuluvainen 1994). Although the length of the chronosequence limits my ability to predict future stand development, I presume that as long as balsam fir is an important component of the stand, dynamics will be characterized by the cyclical replacement of coniferous stands following spruce budworm outbreaks and that small canopy disturbances will remain a minor component of stand dynamics. In the context of a decreasing fire frequency caused both by climate change and fire suppression (Bergeron and Archambault 1993), white cedar may become more and more abundant in the future, a pattern also observed in the Great Lakes mixed forests (Frelich and Reich 1995).

\section{Conclusions}

Although my results confirm that there is considerable variability in post-fire forest composition, succession converges, nonetheless, towards dominance by conifers. This pattern, previously identified using a chronosequence analysis (Bergeron and Dubuc 1989), is confirmed by the use of a stand-reconstruction approach. This convergence appears sufficiently strong in the mixed-wood boreal forest to emerge above the inherent variability and legacies created by different pre-fire compositions and fire behavior (Johnson 1992). This repeated pattern of post-fire succession together with the large variability in composition following individual burns has been also reported by Larsen and MacDonald (1998) in the boreal forest of western Canada.

Species life-history traits such as longevity, type of regeneration, growth rate, and shade tolerance are sufficient to explain the course of the successional process. The main mechanism explaining this convergence involves a higher tolerance of conifers to shade. However, the late arrival of white cedar may be explained by inhibition- or facilitation-related processes. The inhibitory effects of deciduous litter on conifer regeneration has been reported in many studies (Zasada et al. 1992). Similarly, accumulation of coarse woody debris with time since fire may provide safe sites for conifer regeneration (Simard et al. 1998). On the other 
hand, increasing humus depth may be a factor contributing to the decrease in aspen recruitment.

\section{ACKNOWLEDGMENTS}

This work has been supported by the Ministère de l'Enseignement Supérieur et de la Science du Québec (FCAR program), the Ministère des Ressources Naturelles du Québec, and the Natural Sciences and Engineering Research Council of Canada. A very special thanks goes to Danielle Charron, France Conciatori, and Franç ois Ttreault for the field work and the enormous amount of dendrochronological analyses. This research would have not been possible without them. I am also grateful to Alain Leduc for his help in the statistical analyses. I thank Daniel Kneeshaw for comments and advice concerning this manuscript.

\section{Literature Cited}

Archambault, S., and Y. Bergeron. 1992. A 802-year treering chronology from the Quebec boreal forest. Canadian Journal of Forest Research 22:674-682.

Barnes, B. V. 1966. The clonal growth habits of American aspens. Ecology 47:439-447.

Bélanger, L., D. Allard and P. Meek. 1993. Dynamique d'établissement d'un peuplement bi-étagé de bouleau blanc et de sapin baumier en zone boréale. Forestry Chronicle 69:173-177.

Bergeron, Y. 1991. The influence of island and mainland lakeshore landscapes on boreal forest fire regimes. Ecology 72:1980-1992.

Bergeron, Y., and S. Archambault. 1993. Decrease of forest fires in Quebec's southern boreal zone and its relation to global warming since the end of the Little Ice Age. Holocene 3:255-259.

Bergeron, Y., and A. Bouchard. 1984. Use of ecological groups in analysis and classification in a section of western Quebec. Vegetatio 56:45-63.

Bergeron, Y., A. Bouchard, P. Gangloff, and C. Camiré. 1983. La classification écologique des milieux forestiers de la partie ouest des cantons d'Hébécourt et de Roquemaure, Abitibi, Québec. Études écologiques number 9. Les Presses de l'Université Laval, Sainte-Foy, Quebec, Canada.

Bergeron, Y., and J. Brisson. 1990. Fire regime in red pine stands at the northern limit of the species range. Ecology 71:1352-1364.

Bergeron, Y., and J. Brisson. 1994. Effect of climatic fluctuations on post-fire regeneration of two jack pine and red pine populations during the twentieth century. Géographie Physique et Quaternaire 48:145-149.

Bergeron, Y., and D. Charron. 1994. Postfire stand dynamics in the southern boreal forest (Québec): a dendroecological approach. Ecoscience 1:173-184.

Bergeron, Y., and P. R. Dansereau. 1993. Predicting forest composition under different fire cycles in the southeastern boreal forest of Canada. Journal of Vegetation Science 4: $827-832$.

Bergeron, Y., and M. Dubuc. 1989. Succession in the southern part of the Canadian boreal forest. Vegetatio 79:51-63.

Bergeron, Y., H. Morin, A. Leduc, and C. Joyal. 1995. Balsam fir mortality following the last spruce budworm outbreak in northwestern Québec. Canadian Journal of Forest Research 25:1375-1384.

Blais, J. R. 1983. Trends in the frequency, extent, and severity of spruce budworm outbreaks in eastern Canada. Canadian Journal of Forest Research 13:539-547.

Braathe, P. 1995. Birch dieback-cause spring thaws and subsequent frost. Norwegian Journal of Agricultural Sciences, Supplement 20.

Brais, S., and C. Camiré. 1992. Keys for moisture regime evaluation for northwestern Quebec. Canadian Journal of Forest Research 22:718-724.
Burns, R. M., and B. H. Honkala. 1990. Sylvics of North America. USDA Forest Service, Washington, D.C., USA. Carleton, T. J., and P. J. Maycock. 1978. Dynamics of the boreal forest south of James Bay. Canadian Journal of Botany 56:1157-1173.

Cogbill, C. V. 1985. Dynamics of the boreal forests of the Laurentian highlands, Canada. Canadian Journal of Forest Research 21:1779-1795.

Connell, J. H., and R. O. Slatyer. 1977. Mechanisms of succession in natural communities and their role in community stability and organization. American Naturalist 111:11191144.

Dansereau, P. R., and Y. Bergeron. 1993. Fire history in the southern boreal forests of northwestern Quebec. Canadian Journal of Forest Research 23:25-32.

De Grandpré, L., D. Gagnon, and Y. Bergeron. 1993. Changes in the understory of Canadian southern boreal forest after fire. Journal of Vegetation Science 4:803-810.

DesRochers, A., and R. Gagnon. 1997. Is ring count at ground level a good estimation of black spruce age? Canadian Journal of Forest Research 27:1263-1267.

Dix, R. L., and J. M. A. Swan. 1971. The roles of disturbance and succession in upland forest of Candle Lake, Saskatchewan. Canadian Journal of Botany 49:657-676.

Environment Canada. 1993. Canadian climate normals 1961-90. Canadian climate program. Atmospheric Environment Service, Downsview, Ontario, Canada.

Frelich, L. E., and P. B. Reich. 1995. Spatial patterns and succession in a Minnesota southern-boreal forest. Ecological Monographs 65:325-346.

Gagnon, R. 1989. Maintien de limites abruptes entre des peuplements équiens d'épinette noire (Picea mariana) et des formations de feuillus intolérants (Populus tremuloides et Betula papyrifera) dans la région du Saguenay-LacSaint-Jean. Naturaliste Canadien 116:117-124.

Galipeau, C., D. Kneeshaw, and Y. Bergeron. 1997. White spruce and balsam fir colonization of a site in the southeastern boreal forest as observed 68 years after fire. Canadian Journal of Forest Research 27:139-147.

Gauthier, S., J. Gagnon, and Y. Bergeron. 1993. Population age structure of Pinus banksiana at the southern edge of the Canadian boreal forest. Journal of Vegetation Science 3:783-790.

Ghent, A. W., D. A. Fraser, and J. B. Thomas. 1957. Studies of regeneration in forest stands devastated by the spruce budworm. Forest Science 3:184-208.

Glitzenstein, J. F., P. A. Harcombe, and D. R. Streng. 1986. Disturbance, succession, and maintenance of species diversity in an east Texas forest. Ecological Monographs 56: 243-258.

Harvey, B., and Y. Bergeron. 1989. Site patterns of natural regeneration following clear-cutting in northwestern Quebec. Canadian Journal of Forest Research 19:1458-1469.

Heinselman, M. L. 1981. Fire and succession in the conifer forests of North America. Pages 374-406 in D. C. West, H.H. Shugart, and D.B. Botkin, editors. Forest succession: concepts and application. Springer-Verlag, New York, New York, USA.

Hofgaard, A. 1993. Structure and regeneration patterns of a virgin Picea abies forest in northern Sweden. Journal of Vegetation Science 4:601-608.

Holmes, R. L. 1983. Computer-assisted quality control in tree-ring dating and measurement. Tree-ring Bulletin 43: 69-78.

Johnson, E. A. 1992. Fire and vegetation dynamics - studies from the North American boreal forest. Cambridge studies in ecology. Cambridge University Press, Cambridge, UK.

Johnson, E. A., and G. I. Fryer. 1989. Population dynamics in lodgepole pine-engelman spruce forests. Ecology 70: 1335-1345. 
Jones, R. K., G. Pierpoint, G. M. Wickware, J. K. Jeglum, R. W. Arnup, and J. M. Bowles. 1983. Field guide to forest ecosystem classification for the clay belt, site region $3 \mathrm{e}$. Ministry of Natural Resources, Ontario, Canada.

Kneeshaw, D. D., and Y. Bergeron. 1996. Ecological factors affecting the abundance of advanced regeneration in Quebec's southwestern boreal forest. Canadian Journal of Forest Research 26:888-898.

Kneeshaw, D., and Y. Bergeron. 1998. Canopy gap characteristics and tree replacement in the southeastern boreal forest. Ecology 79:783-794.

Kuuluvainen, T. 1994. Gap disturbance, ground microtopography, and the regeneration dynamics of boreal coniferous in Finland: a review. Annals Zoology Fenncici 31:131-143.

Larsen, C. P. S., and G. M. MacDonald. 1998. An 840-year record of fire and vegetation in a boreal white spruce forest. Ecology 79:106-118.

Lavertu, D., Y. Mauffette, and Y. Bergeron. 1994. Suckering success of aspen (Populus tremuloides Michx.) in relation to stand age and soil disturbance. Journal of Vegetation Science 5:561-568.

Liu, K.-B. 1990. Holocene paleoecology of the boreal forest and Great Lakes-St. Lawrence forests in northern Ontario. Ecological Monographs 60:179-212.

Lorimer, C. G. 1980. Age structure and disturbance history of a southern Appalachian virgin forest. Ecology 61:11691184.

Lorimer, C. G. 1985. Methodological considerations in the analysis of forest disturbance history. Canadian Journal of Forest Research 15:200-213.

MacLean, D. A. 1980. Vulnerability of fir-spruce stands during uncontrolled spruce budworm outbreaks: a review and discussion. Forestry Chronicle 56:213-221.

MacLean, D. A., and D. P. Ostaff. 1989. Patterns of balsam fir mortality caused by an uncontrolled spruce budworm outbreak. Canadian Journal of Forest Research 19:10871095.

Marks, P. L. 1974. The role of pin cherry (Prunus pensylvanica) in the maintenance of stability in northern hardwood ecosystems. Ecological Monographs 44:73-88.

Martineau, R . 1985. Insectes nuisibles des forêts de l'est du Canada. Marcel Broquet, Ottawa, Ontario, Canada.

Morin, H. 1990. Dendro-ecological analysis of a boreal fir population resulting from a blowdown in Quebec. Canadian Journal of Forest Research 20:1753-1758.

Morin, H. 1994. Dynamics of balsam fir forests in relation to spruce budworm outbreaks in the boreal zone, Québec. Canadian Journal of Forest Research 24:730-741.

Morin, H., D. Laprise, and Y. Bergeron. 1993. Chronology of spruce budworm outbreaks in the Lake Duparquet region, Abitibi, Québec. Canadian Journal of Forest Research 23:1497-1506.

Oliver, C. D., and B. C. Larson. 1990. Forest stand dynamics. McGraw Hill, New York, New York, USA.

Palik, B. J., and K. S. Pregitzer. 1991. The relative influence of establishment time and height-growth rates on species vertical stratification during secondary forest succession. Canadian Journal of Forest Research 21:1481-1490.

Paré, D., and Y. Bergeron. 1996. Influence of colonizing trees on soil properties following fire in the Canadian southern boreal forest. Canadian Journal of Forest Research 26: $1022-1031$.
Payette, S., L. Filion, and A. Delwaide. 1990. Disturbance regime of a cold temperate forest as deduced from treerings pattern: the Tantaré Ecological Reserve, Québec. Canadian Journal of Forest Research 20:1228-1241.

Peterson, E. B., and N. M. Peterson. 1992. Ecology, management, and use of aspen and balsam poplar in the prairie provinces. Special Report 1. Forestry Canada, Northwest Region, Northern Forestry Center, Edmonton, Alberta, Canada.

Qinghong, L., and H. Hytteborn. 1991. Gap structure, disturbance and regeneration in a primeval Picea abies forest. Journal of Vegetation Science 2:391-402.

Richard, P. J. H. 1993. Origine et dynamique postglaciaire de la forêt mixte au Québec. Review of Paleobotany and Palynology 79:31-68.

Rowe, J. S. 1972. Forest regions of Canada. Environment Canada, Ottawa, Ontario, Canada.

Runkle, J. R. 1981. Gap regeneration in some old-growth forests of the eastern United States. Ecology 62:10411051.

Scott, M. L., and P. G. Murphy. 1987. Regeneration of northern white cedar, an old-growth forest dominant. American Midland Naturalist 117:10-16.

Shields, W. J., Jr., and J. G. Bockheim. 1981. Deterioration of trembling aspen clones in the Great Lakes Region. Canadian Journal of Forest Research 11:530-537.

Simard, M. J., Y. Bergeron, and L. Sirois. 1998. Conifer recruitment in the southeastern Canadian boreal forest: the importance of substrates. Journal of Vegetation Science 9: $575-582$.

Sims, R. A., H. M. Kershaw, and G. M. Wickware. 1990. The autecology of major tree species in the north central region of Ontario. COFRDA report 3302. Canada-Ontario Forest Resource Development Agreement, Canadian Forestry Service, Sault-Ste-Marie, Ontario, Canada.

Sirois, L., and S. Payette. 1989. Postfire black spruce establishment in subarctic and boreal Quebec. Canadian Journal of Forest Research 19:1571-1580.

ter Braak, C. J. F. 1988. CANOCO—FORTRAN program for canonical community ordination by [partial] [detrended] [canonical] correspondance analysis, principal components analysis and redundancy analysis. Version 2.1. TNO Institute of Applied Computer Science, Wageningen, The Netherlands.

Van Wagner, C. E. 1983. Fire behaviour in northern conifer forests. Pages 45-80 in R.W. Wein and D. A. MacLean, editors. The role of fire in northern circumpolar ecosystems. John Wiley \& Sons, New York, New York, USA.

Veillette, J. J. 1994. Evolution and paleohydrology of glacial lakes Barlow and Ojibway. Quaternary Science Review 13: 945-971.

Viereck, L. A. 1983. The effects of fire in black spruce ecosystems of Alaska and northern Canada. Pages 201-220 in R.W. Wein and D. A. MacLean, editors. The role of fire in northern circumpolar ecosystems. John Wiley \& Sons, New York, New York, USA.

Zasada, J., T. L. Sharik, and M. Nygren. 1992. The reproductive process in boreal forest trees. Pages 85-125 in H.H. Shugart, R. Leemans, and G. B. Bonan, editors. A systems analysis of the boreal forest. Cambridge University Press, Cambridge, UK.

\section{APPENDIX}

Results for individual stands plus additional data are available in ESA's Electronic Data Archive: Ecological Archives E081-018. The archived material includes: A1. Maps of dead stems for each stand; A2. Combined age structure of the regeneration for the eight stands; A3. Age structures for all living and dead stems, per stand and per species (1760-1986); A4. Frequency of mortality per stand and per species (1760-1990); and A5. Frequency of stems $\geq 5 \mathrm{~cm}$ dbh, per stand and per species $(1760-1990)$. 